\title{
A new species of Paraphysiana (Hemiptera: Cicadellidae: Neocoelidiinae) from French Guiana
}

With 12 figures

Clayton Corrêa Gonçalves ${ }^{1,2}$, Beatriz Macharet Camisão'

${ }^{1}$ Laboratório de Entomologia, Departamento de Zoologia, Instituto de Biologia, Universidade Federal do Rio de Janeiro, Caixa Postal 68044, Rio de Janeiro, 21941-971, RJ, Brasil.

${ }^{2}$ Bolsista CAPES, Programa de Pós-graduação em Zoologia, Museu Nacional, Universidade Federal do Rio de Janeiro, Brasil. clayton.correa.goncalves@gmail.com

Published on 2015-06-30

\section{Summary}

A new species of Paraphysiana Chiamolera, Cavichioli \& Anderle (2003), P. marquescostae spec. nov., is described and illustrated. The new species can be distinguished from the other species of the genus by the following characteristics: (1) pygofer with a pair of inner dorsal processes; (2) pygofer with a pair of inner ventral processes are curved dorsally and twisted apically.

\section{Key words}

Description, Neotropical Region, leafhopper, taxonomy

\section{Zusammenfassung}

Eine neue Art der Gattung Paraphysiana Chiamolera, Cavichioli \& Anderle (2003), P. marquescostae spec. nov., wird beschrieben und dargestellt. Die beschriebene Art kann von den anderen Arten der Gattung durch folgende Merkmale unterschieden werden: (1) letztes Abdominalsegment dorsal mit einem Paar innerer Fortsätze; (2) letztes Abdominalsegment ventral mit einem Paar innerer Fortsätze, die dorsal gekrümmt und apikal verdreht sind.

\section{Introduction}

Neocoelidiinae is a small subfamily of Cicadellidae, comprising 174 species in 33 genera (GonçALVES et al. 2012, Marques-Costa \& Cavichioli 2012). The subfamily is restricted to the New World. Paraphysiana Chiamolera, Cavichioli \& Anderle (2003) is a monotypic genus that was proposed for P.diminuta Chiamolera, Cavichioli \& Anderle, 2003 from Amazonas State, Brazil.
Paraphysiana can be easily distinguished from other genera of Necoelidiinae by the following set of characteristics: (1) head without carena between crown and face; (2) male pygofer with inner ventral process; (3) subgenital plates entirely fused to each other; (4) aedeagus subcylindrical; (5) paraphysis long (CHiAmolera et al. 2003). According to a cladistic analysis based on morphological data (MARques-Costa \& CAVichioli 2012), Paraphysiana is the sister group of Deltocoelidia KRAMER, 
1961, supported by three homoplastic apomorphies: (1) head, in lateral view, with apex rounded; (2) frontogenal sutures not reaching the ocelli; and (3) metatibiae with anterovental row (AV) of setae absent on basal third. In this paper, a new species, $P$. marquescostae spec. nov., is described based on a single male specimen collected in French Guiana, which is deposited in the Coleção Entomológica Professor José Alfredo Pinheiro Dutra (DZRJ), Rio de Janeiro.

\section{Material and Methods}

For the analysis of the genital structures, the abdomen was removed and placed in hot $10 \% \mathrm{KOH}$, following OMAN (1949). Genitalia were washed for 5-10 minutes in hot water and placed on a concave slide with glycerin for examination and preparation of photographs. The genitalia were stored in a small vial with glycerin and pinned to the specimen's pin. Photographs were taken with a camera attached to a Leica stereomicroscope, using the image stacking software CombineZP. Illustrations were made with a stereoscopic microscope with a camera lucida attached. The morphological terminology follows mainly DiETRICH (2005), except for the head sclerites (Hamilton 1981, Mejdalani 1998). The terms for the leg chaetotaxy follow RAKiTov (1997).

\section{Taxonomy}

\section{Paraphysiana marquescostae spec. nov.} (Figs 1-12)

Type-locality: Petite Montagne Tortue, French Guiana.

Material examined: Male holotype: "FRENCH GUIANA: Petite $\backslash$ Montagne Tortue P $11 \backslash 04^{\circ} 19^{\prime} 14.1 \mathrm{~N}-052^{\circ} 14^{\prime} 27.5 \mathrm{~W} \backslash$ 24.XI.2010 Lamarre G. Leg" "White sand forest \Vitre trap (V12)" (DZRJ).

Diagnosis: Forewings (Fig. 4) with five dark brown maculae near inner margin; male pygofer (Fig. 5) with inner dorsal processes in apical half and inner ventral processes, twisted at apex; subgenital plates (Figs 6, 7) with dorsal apical tooth; connective (Fig. 8) T-shaped; styles (Figs 8,9 ) with apex bifid, chela-shaped; aedeagus (Fig. 10) tubular, without process.

Length: Male holotype: $5.9 \mathrm{~mm}$.

General color: Body (Figs 11, 12) with ground color pale yellow. Crown, face, pronotum and mesonotum (Figs 1-3) unmarked. Forewings (Fig. 4) yellow hyaline; orange band adjacent to inner margin, extending from basal angle to clavus apex; five dark brown maculae near inner margin, three on clavus and two on corium, on brachial cell and inner anteapical cell; apex fuscous. Legs (Figs 11, 12) pale yellow.

External morphology: Crown (Fig. 1) about as long as wide; flattened. Pronotum (Figs 1, 3) about 2.7 times wider than long; posterior margin concave. Mesonotum (Fig. 1) about as long as wide. Forewings (Fig. 4) with venation indistinct except apically; with three anteapicall cells and four apical cells; appendix narrow, extending to first apical cell.

Male genitalia: Pygofer, in lateral view (Fig. 5), approximately triangular, higher basally and slightly tapering towards apex; with two pairs of inner processes: one pair longer, slender and sclerotized, adjacent to ventral margin, extending from base to apex of pygofer, with apices twisted and acute, and one dorsal pair shorter, extending from base of anal tube to apex of pygofer, apices sclerotized and hook-shaped; few short setae distributed on apical third. Subgenital plates extending to apex of pygofer; fused meadlly to the valve; completely fused to each other; in ventral view (Fig. 6), approximately triangular, enlarged at base and narrowing toward apex; dorsal surface with sclerotized longitudinal band in middle third, where the styles are attached; apex rounded, with several fine setae; in lateral view (Fig. 7), with pre-apical dorsal tooth. Connective, in dorsal view (Fig. 8), T-shaped, approximately $1 / 3$ of length of styles; articulated to base of paraphysis. Styles (Figs 8,9$)$ long and slender; apex chela-shaped, dorsal branch more slender, with median tooth on lateral inner margin, ventral branch more robust, with dorsal apical tooth. Paraphysis (Fig. 10) long, almost twice the length of aedeagus; connecting anteroventral portion of connective to atrial region of aedeagus. Aedeagus (Fig. 10) with tubular shaft bent dorsoanteriorly; apex acute; dorsal apodeme nearly as long as shaft; gonophore apical. Anal tube membranous, without processes.

Female unknown.

Etymology: The species name is a tribute to Dr. Ana Paula Marques-Costa, due to her contribution to the knowledge of Cicadellidae, especially Neocoelidiinae, and also due to a great friendship and for introducing the first author of this paper to the study of the group.

Notes: Paraphysiana marquescostae spec. nov. can be easily distinguished from $P$. diminuta by the characters of the male pygofer. The new species has a pair of inner dorsal processes (Fig. 5) on the male pygofer, which is absent in $P$. diminuta. Furthermore, the inner ventral processes of the pygofer in $P$. marquescostae are curved dorsally and twisted apically, while in P. diminuta the inner ventral processes are approximately straight and not twisted. 

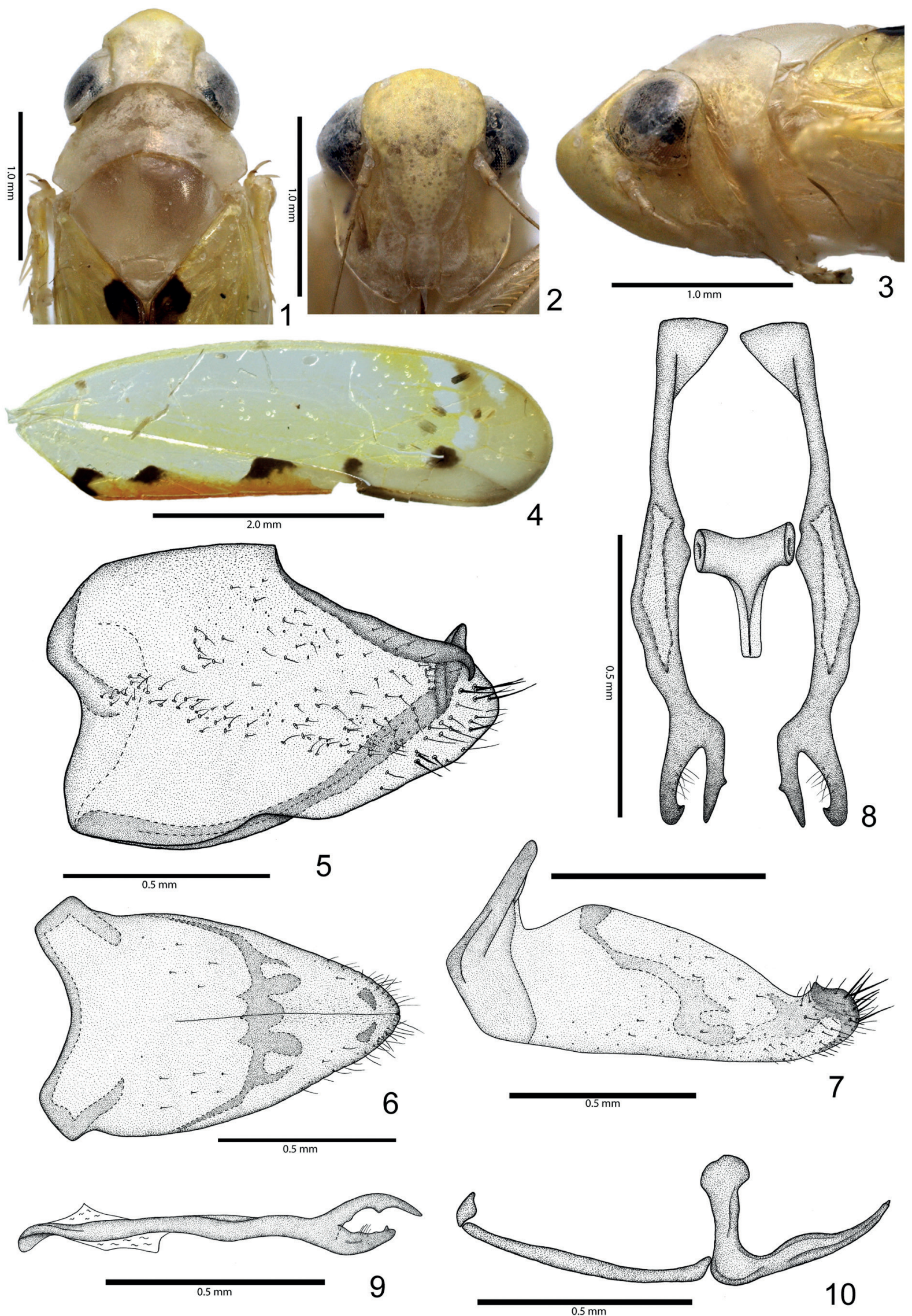

Figs 1-10: Paraphysiana marquescostae spec. nov., male holotype. 1, anterior portion of body, dorsal view. 2, head, frontal view. 3 , anterior portion of body, lateral view. 4, forewing. 5, pygofer, lateral view. 6, subgenital plates, ventral view. 7, subgenital plates, lateral view. 8, connective and styles, dorsal view. 9, style, lateral view. 10, aedeagus, connective and paraphysis, lateral view. 


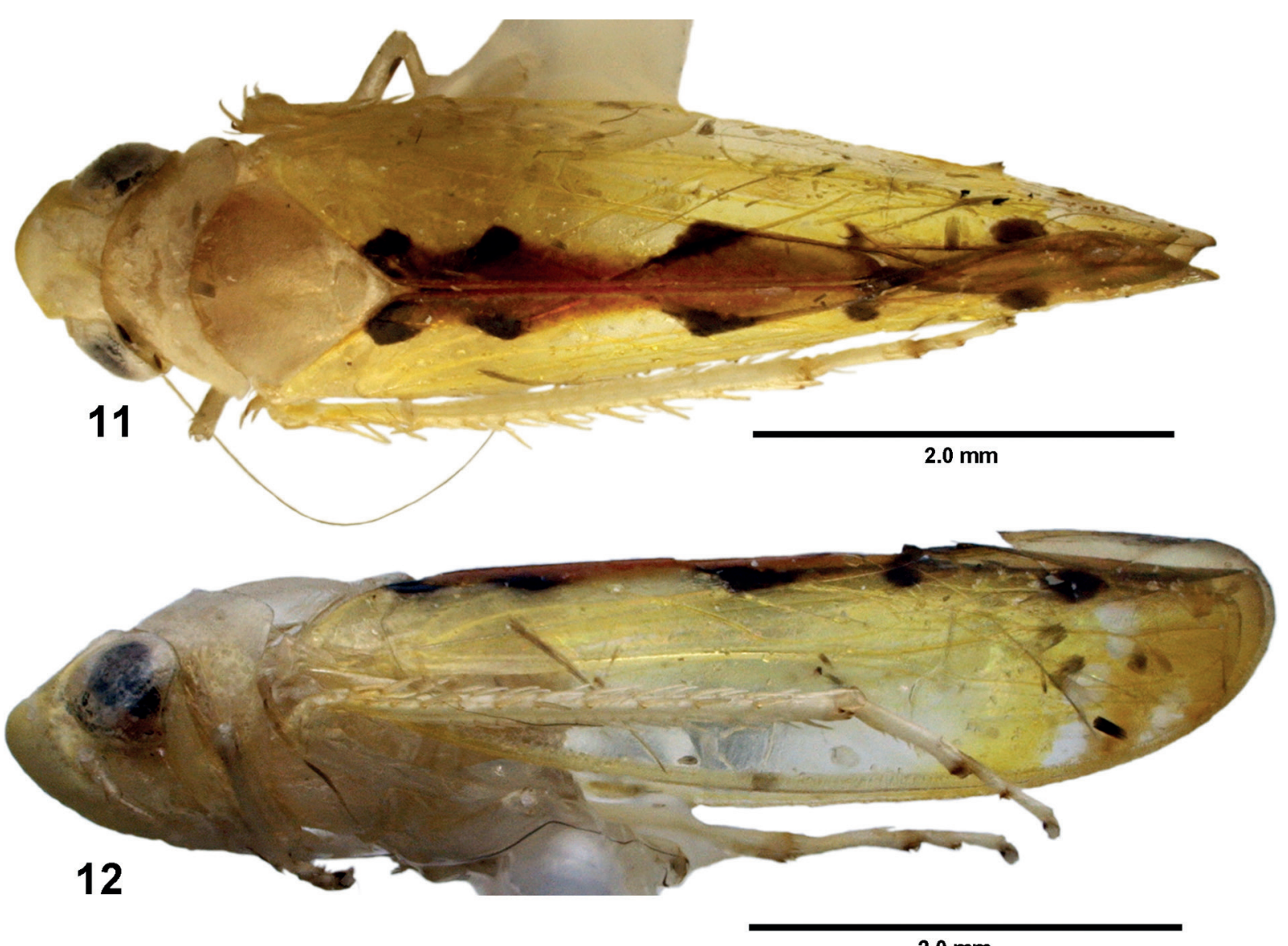

Figs 11-12: Paraphysiana marquescostae spec. nov., male holotype: 11, body in dorsal view. 12, body in lateral view.

\section{Acknowledgements}

The authors would like to thank the Laboratório de Entomologia, UFRJ, for the use of equipment and material. Financial support given as a CAPES fellowship to the senior author.

\section{References}

Chiamolera, L. B.; Cavichioli, R. R. \& Anderle, P. N. 2003: Gênero e espécie nova de Neocoelidiinae (Hemiptera: Auchenorrhyncha: Cicadellidae). Neotropical Entomology 32 (3): 433-435.

Dietrich, C. H. 2005: Key to the families of Cicadomorpha and subfamilies and tribes of Cicadellidae (Hemiptera: Auchenorrhyncha). - Florida Entomologist 88: 502-517.

Gonçalves, C. C.; Marques-Costa, A. P. \& AleRocha, R. 2012: Placoscopana, a new genus of Neocoelidiinae (Hemiptera: Cicadellidae) from Ecuador. - Zoologia 29 (5): 483-487.

Hamilton, K. G. A. 1981: Morphology and evolution of the rhynchotan head (Insecta: Hemiptera, Homoptera). - Canadian Entomologist 113: 953-974.
Marques-Costa, A. P. \& Cavichioli, R. R. 2012: Cladistic analysis of Neocoelidiinae (Hemiptera: Cicadellidae) with description of a new tribe. Zootaxa 3483: 1-28.

Mejdalani, G. 1998: Morfologia externa dos Cicadellinae (Homoptera, Cicadellidae): comparação entre Versigonalia ruficauda (WALKER) (Cicadellini) e Tretogonia cribrata Melichar (Proconiini), com notas sobre outras espécies e análise da terminologia. - Revista Brasileira de Zoologia 15: 451-544.

OMAN, P. W. 1949: The Nearctic leafhoppers (Homoptera: Cicadellidae). A generic classification and check list. Memoirs of the Entomological Society of Washington 3: 1-253.

Rakitov, R. A. 1997: On differentiation of cicadellid leg chaetotaxy (Homoptera: Auchenorrhyncha: Membracoidea). - Russian Entomological Journal 6: 7-27. 